The habits of using language of structures of A2 level students learning Turkish as a foreign language / Ö. Çangal; A. Kıribiș (pp. 5664)

\title{
05. Yabancı dil olarak Türkçe öğrenen A2 düzeyi öğrencilerinin dil yapılarını kullanma alışkanlıkları
}

\section{Önder ÇANGAL ${ }^{1}$ \\ Ali KIRİBiş̧²}

APA: Çangal, Ö.; Kıribiş, A. (2021). Yabancı dil olarak Türkçe öğrenen A2 düzeyi öğrencilerinin dil yapılarını kullanma alışkanlıkları. RumeliDE Dil ve Edebiyat Araștırmaları Dergisi, (Ö9), . 56-64. DOI: $10.29000 /$ rumelide. 984723

\section{Öz}

Temel düzey (A1-A2), yabancı dil öğretiminde önemli bir eşiktir. Toplumsal işlevleri gösteren tanımlayıcıların çoğu bu düzeydedir. Yolculukta, yurt dışında ve günlük hayatta dilsel etkileşim için gerekli, temel ihtiyaçların giderilmesi için kazanılması gereken yeterliklere de bu düzeyde yer verilmektedir (TELC, 2013, s. 39). Dolayısıyla temel düzeyi bitiren bir yabancıdan kendisini hedef dilde rahatlıkla ifade etmesi ve günlük hayatını sorunsuz bir şekilde sürdürmesi beklenmektedir. Yabancı dil olarak Türkçe öğrenenlerin okuma, dinleme, konuşma ve yazma becerilerinin geliştirilmesi, süreçte becerilerle birlikte öğrencilere dil bilgisi yapılarının öğretilmesi hedeflenmektedir. Dil bilgisi ayrı bir beceri olarak değerlendirilmemektedir. Fakat özellikle üretici beceriler olarak adlandırılan konuşma ve yazmanın geliştirilmesinde dil bilgisi önemli bir yere sahiptir. Öğrenciler öğrendikleri dil yapılarını konuşarak ve yazarak deneyimleme imkânı bulmaktadır. Bu araștırmada Türkiye'de yabancı dil olarak Türkçe öğrenen A2 düzeyindeki öğrencilerin dil bilgisi yapılarını kullanma alışkanlıkları araştırılmıştır. Dil bilgisi yapılarının belirlenmesinde Türkiye Maarif Vakfı (2020) tarafından hazırlanan "Türkçenin Yabancı Dil Olarak Öğretimi Programı” esas alınmış, öğrencilerin yazma kâğıtlarında bu yapılardan hangi sıklıkla yararlandıkları incelenmiştir. Araştırma A2 düzeyi öğrencilerinin en çok kullandıkları dil bilgisi yapılarını ortaya koyması açısından önem arz etmektedir. Türkçeyi yabancı dil olarak Türkiye'de öğrenen öğrencilerin en çok ihtiyaç duydukları ve kullandıkları dil bilgisi yapılarının tespit edilmesinin dil öğretim süreçlerinin planlanmasına ve öncelikli dil bilgisi yapılarının tespit edilmesine yardım etmesi beklenmektedir.

Anahtar kelimeler: Yabancı dil olarak Türkçe öğretimi, yazma becerisi, dil bilgisi yapılarının kullanımı

\section{The habits of using language of structures of A2 level students learning Turkish as a foreign language}

\begin{abstract}
The basic level (A1-A2) is an important threshold in foreign language teaching. Most descriptors of social functions are at this level. Competencies required for linguistic interaction in travel, abroad and in daily life and which must be acquired to meet basic needs are also included at this level (TELC, 2013, p. 39). Therefore, a foreigner who has completed the basic level is expected to express himself easily in the target language and to continue his daily life without any problems. It is aimed to develop the reading, listening, speaking and writing skills of those who learn Turkish as a foreign language, and to teach
\end{abstract}

1 Öğr. Gör Dr., Gaziantep Üniversitesi, Türkçe Öğretimi Uygulama Ve Araştırma Merkezi (Gaziantep, Türkiye). ondercangal@hotmail.com, ORCID ID: 0000-0002-8560-3526. [Araştırma makalesi, Makale kayıt tarihi: 26.07.2021-kabul tarihi: 20.08.2021; DOI: 10.29000/rumelide.984723]

2 YL, Kırșehir Ahi Evran Üniversitesi, Sosyal Bilimler Enstitüsü, Türkçe Eğitimi, (Kırșehir, Türkiye). alikiribis@icloud.com, ORCID ID: 0000-0002-1751-1160

Adres
RumeliDE Dil ve Edebiyat Araştırmaları Dergisi Osmanağa Mahallesi, Mürver Çiçeği Sokak, No:14/8 Kadıköy - ISTANBUL / TÜRKIYE 34714 e-posta: editor@rumelide.com tel: +90 $5057958124,+902167730616$
Address

RumeliDE Journal of Language and Literature Studies Osmanağa Mahallesi, Mürver Çiçeği Sokak, No:14/8

Kadıköy - ISTANBUL / TURKEY 34714

e-mail: editor@rumelide.com,

phone: +90 5057958124 , +90 2167730616 
grammar structures together with the skills in the process. Grammar is not considered a separate skill. However, grammar has an important place in the development of speaking and writing, which are called productive skills. Students have the opportunity to experience the language structures they have learned by speaking and writing. In this study, the habits of using grammatical structures of A2 level students learning Turkish as a foreign language in Turkey were investigated. In determining the grammar structures, the "Teaching Turkish as a Foreign Language Program" prepared by the Turkish Maarif Foundation (2020) was taken as a basis, and it was examined how often the students benefited from these structures in their writing papers. The research is important in terms of revealing the grammar structures that A2 level students use most. It is expected that determining the grammatical structures that the students learning Turkish as a foreign language most need and use in Turkey will help to plan the language teaching processes and to determine the primary grammatical structures.

Keywords: Teaching Turkish as a foreign language, writing skills, use of grammatical structures

\section{Giriş}

Günümüzde Türk dizilerinin de etkisiyle dünyanın farklı ülkelerinden insanlar Türkçe öğrenmek istemekte, bu amaçla farklı Türk kurum ve kuruluşlarının düzenlediği yüz yüze veya çevrim içi Türkçe kurslarına katılmaktadır. Yine farklı gerekçelerle Türkiye'ye gelen yabancılar üniversitelerin Türkçe Öğretimi Uygulama ve Araştırma Merkezleri ile özel dil kurslarında Türkçe öğrenmekte, Yurtdışı Türkler ve Akraba Topluluklar Başkanlığı tarafından düzenlenen "Türkiye Bursları" programı sayesinde yükseköğrenim görmek isteyen yabancılar Türkiye'yi tercih etmektedir. Öğrenci, kurs ve ders veren kurum sayılarının artması yabancılara Türkçe öğretimi alanı adına olumlu bir gelişmedir. Bununla birlikte bir diğer önemli husus yabancılara Türkçe öğreten kurumlar arasında bir standart olması, eğitimin kalitesinin ve öğrenci başarısının Türkçe öğreten bir kurumdan diğerine değişiklik göstermemesidir.

Avrupa Konseyi, üye ülkeler arasında çok dilliliğin teşvik edilmesi ve dil öğretim süreçlerinde standartların sağlanması amaçlarıyla 2001 yılında "Diller için Avrupa Ortak Başvuru Metni”ni (OBM) yayımlamıştır. Dil öğretim süreçlerinin planlanmasında bir çerçeve sunmak amacıyla hazırlanan OBM, üye ülkelere yol gösterici olma özelliği göstermekte; üye ülkelerin OBM'den hareketle kendi dillerinin öğretimi için bir program hazırlaması tavsiye edilmektedir.

Konsey, 5 Mayıs 1949'da Belçika, Danimarka, Fransa, Hollanda, İngiltere, İrlanda, İsveç, İtalya, Lüksemburg ve Norveç'in imzaladığı anlaşma ile kurulmuş; aynı yılın Ağustos ayında Yunanistan ve Türkiye, Avrupa Konseyi'ne kurucu üye olarak katılmıştır (Türkiye Büyük Millet Meclisi, 2021). Türkiye'nin Avrupa Konseyi üyesi olması nedeniyle OBM yayımlandıktan sonra yabancılara Türkçe öğreten kurumlar kendi kurs süreçlerini ve ders kitaplarını yayımlanan metne göre yeniden düzenlemiştir. OBM'nin üye ülkelere bir çerçeve çizmesi nedeniyle zamanla yabancılara Türkçe öğretimi özelinde bir program hazırlanması ihtiyacı ortaya çımıştır. Bu ihtiyacın giderilmesi amacıyla Yunus Emre Enstitüsü 2011'de, Ankara Üniversitesi 2015'te ve Türkiye Maarif Vakfı 2019'da Türkçenin yabancı dil olarak öğretimi programları hazırlamıştır. Yunus Emre Enstitüsü, hazırlamış olduğu programı yayımlamamış; fakat enstitüye ait ders kitaplarının ve materyallerinin geliştirilmesinde bu programı temel almıştır. Ankara Üniversitesi TÖMER'in çabaları ile hazırlanan programın kullanımı yaygınlık kazanmazken Türkiye Maarif Vakfı (TMV) tarafından hazırlanan program geliştirilerek 2020 yılı baskısı ile MEB Talim ve Terbiye Kurulu Başkanlığının onayını alan ilk “Türkçenin Yabancı Dil Olarak Öğretimi Programı” olmuştur.

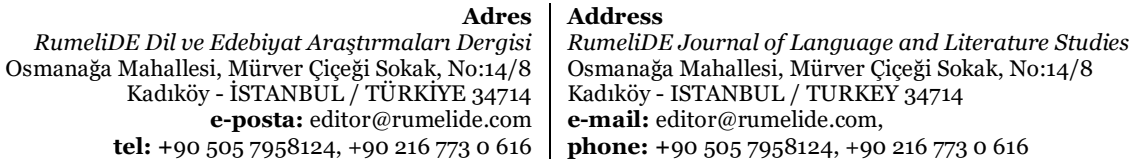

RumeliDE Dil ve Edebiyat Araştırmaları Dergisi tel: +90 505 7958124, +902167730616 
The habits of using language of structures of A2 level students learning Turkish as a foreign language / Ö. Çangal; A. Kıribiș (pp. 5664)

TMV programı; hem A1 düzeyinden C1'e kadar okuma, dinleme, konuşma ve yazma kazanımlarının listelendiği yabancılara Türkçe öğretimi programı hem de TMV ve MEB'e bağlı okullarda yurt içinde ve yurt dışında kullanılmak üzere hazırlanan yabancı çocuklar için Türkçe öğretimi müfredatı olma özelliği göstermektedir. Program ile "anlama ve anlatma becerilerini kullanarak sosyal hayatın her alanında iletişim kurma becerisine sahip olan, keșfederek ve yaparak-yaşayarak öğrenen, öğrenme sürecinde sorumluluk alan, iş birliği içinde çalışan, problem çözme becerilerini kullanan, sorgulayan, yorumlayan, evrensel ve kendi kültürüne özgü değerlere duyarlı, kültürlerarası bilinç sahibi bireyler yetiştirmek ..." (Türkiye Maarif Vakfl, 2020, s. 13) istenmekte; program yabancılara Türkçe öğretecek kurumlar için başvuru kaynağı olması, dil öğretim süreçlerinin planlanmasında bir standart ortaya koyması ve öğrencilere verilmesi gereken dil bilgisi yapılarını düzeylere göre listelemesi nedeniyle önem arz etmektedir.

Eylem odaklı yaklaşım esas alınarak hazırlanan OBM, öğretilecek dilin her ortamda ve koşulda aktif olarak kullanılabilmesini tavsiye etmekte, dilin iletişim boyutunu ön plana çıkarmaktadır. Bu bağlamda OBM'den hareketle düzenlenen dil kurslarındaki amaç da öğrencilerin günlük hayatlarında kullanabilecekleri ve etkileşim kurabilecekleri Türkçeyi öğrenmelerini sağlamaktır. Türkiye'deki üniversitelerin TÖMER'lerinde bu duruma ne derece dikkat edildiği araştırılması gereken bir konudur. Özellikle öğrencilere günlük hayatta kullanmayacakları dil bilgisi yapılarını dayatmak "öğretilecek dilin işlevsel olması” ilkesine aykırı bir durum teşkil edecektir. Bu nedenle Türkçe öğrenen yabancıların doğal kullanım ortamlarında nasıl bir dil kullanım alışkanlığı kazandığını tespit etmek ve tespitlerden hareketle dil öğretim süreçlerinin geliştirilmesine yönelik öneriler ortaya koymak gerekmektedir.

\section{Araştırmanın amacı}

Araştırmanın amacı yabancı dil olarak Türkçe öğrenen A2 düzeyi öğrencilerinin dil bilgisi yapılarını kullanma alışkanlıklarını tespit etmek, tespitlerden hareketle dil öğretim süreçlerini kolaylaştırmaya yönelik öneriler sunmaktır.

\section{Araștırmanın önemi}

$\mathrm{Bu}$ araştırmada Türkiye'de yabancı dil olarak Türkçe öğrenen A2 düzeyindeki öğrencilerin dil bilgisi yapılarını kullanma alışkanlıkları araştırılmıştır. Dil bilgisi yapılarının belirlenmesinde Türkiye Maarif Vakfı (2020) tarafından hazırlanan “Türkçenin Yabancı Dil Olarak Öğretimi Programı” esas alınmıș, öğrencilerin yazma kâğıtlarında bu yapılardan hangi sıklıkla yararlandıkları incelenmiştir.

Bulgular toplandıktan sonra TMV programı "düzeylere göre dil yapıları listesi" incelenmiş; alfabe ve ses olayları gibi temel dil yapıları ile öğrenciler tarafından yazma kâğıtlarında kullanılmayan dil yapıları araștırma için kullanılacak "A1-A2 Düzeyi Dil Bilgisi Yapıları" listesine dâhil edilmemiştir. Bu bağlamda A1 düzeyinde "alfabe, ünlü ve ünsüz ayrımı, ünlü ve ünsüzlerin özellikleri, ses olayları, belirsizlik zamirleri, işaret sıfatları, istek/dilek I. çekim, isim tamlamaları, ek fiil belirli geçmiş zamanı, sıralama sayıları, saat kaç, sayılar ve temel niteleyiciler"; A2 düzeyinde "ek fiil (görülen ve duyulan geçmiş zaman) ve zarflar" dil yapıları listesinin dişında tutulmuştur.

TMV programından hareketle hazırlanan ve araştırmada kullanılan "A1-A2 düzeyi dil bilgisi yapıları listesi" şu şekildedir:

Tablo 1. A1-A2 Düzeyi Dil Bilgisi Yapıları 


\begin{tabular}{|c|c|c|}
\hline 1 & Şahıs ve İşaret Zamirleri & Gelecek Zaman + Zaman Zarfları \\
\hline 2 & İyelik Ekleri & Görülen Geçmiş Zaman + Zaman Zarfları \\
\hline 3 & İlgi Zamiri (benimki...) & Duyulan Geçmiş Zaman + Zaman Zarfları \\
\hline 4 & Basit Emir Cümleleri & Geniş Zaman + Sıklık Zarfları \\
\hline 5 & Ek Fiil Geniş Zaman & Zamirler, zamir + ki (Benimki) \\
\hline 6 & Hâl Ekleri - Fiil İlişkisi & Sifatlar \\
\hline 7 & Şimdiki Zaman & Zarf Fiiller (-Ip, -ArAk, -mAdAn, -A ... -A) \\
\hline 8 & Olumsuzluk Eki (-mA) & Gereklilik Kipi \\
\hline 9 & Basit Adlaștırmalar (-mAk iste-/-mAyI sev-) & Dilek-Şart Kipi \\
\hline 10 & Görülen Geçmiş Zaman & Yeterlik Fiili \\
\hline 11 & Geniş Zaman & $\begin{array}{l}\text { Bağlaçlar (hem ... hem, ne ... ne, veya, belki, ya ... ya, } \\
\text { dA) }\end{array}$ \\
\hline 12 & Gelecek Zaman & -mAdAn önce/-DIkTAn sonra \\
\hline 13 & $\begin{array}{l}\text { Zaman Zarfları (dün, bugün, yarın; önce, şimdi, } \\
\text { sonra) }\end{array}$ & Gibi, Kadar (benzetme/karşılaştırma) \\
\hline 14 & $\begin{array}{l}\text { Sıklık Zarfları (bazen, ara sıra, her zaman, } \\
\text { genellikle...) }\end{array}$ & -cA, -A göre \\
\hline 15 & Karşılaştırma Yapıları -DAn, -DAn daha... & Bu yüzden / Bu sebeple \\
\hline 16 & Üstünlük Derecesi: en & Sifat Fiil (-An) \\
\hline 17 & -DAki, DAn ... A kadar, DAn, beri, -DIr & -mAk için, -mAk üzere, -mAsI için \\
\hline 18 & Yapım Ekleri: -Il/-sIz & Mesela, Örneğin \\
\hline 19 & Bağlaçlar: ile, ve, ama, çünkü & Doğrudan Anlatım (diye sor-/diye cevap ver-) \\
\hline 20 & Temel Soru İfadeleri & Ünlemler / İkilemeler / Kesinlikle, Mutlaka \\
\hline 21 & -DAn önce/-DAn sonra & -I beğen-, -I beğenme-, -I tercih et-, -I seç- \\
\hline 22 & -cA/-A göre & Sadece, Değil, Ayrıca/Aynı Zamanda \\
\hline
\end{tabular}

Türkiye Maarif Vakfı, 2020, s. 83

Üretici beceriler olarak da adlandırılan konuşma ve yazmanın geliştirilmesinde dil bilgisi önemli bir yere sahiptir. Öğrenciler öğrendikleri dil yapılarını konuşarak ve yazarak deneyimleme imkânı bulmaktadır.

\section{Yöntem}

$\mathrm{Bu}$ çalışmada doküman analizi yönteminden yararlanılmıştır. Doküman analizi, yazılı belgelerin içeriğini titizlikle ve sistematik olarak analiz etmek için kullanılan bir nitel araştırma yöntemidir (Wach, 2013). Doküman analizi, basılı ve elektronik materyaller olmak üzere tüm belgeleri incelemek ve değerlendirmek için kullanılan sistemli bir yöntemdir. Nitel araştırmada kullanılan diğer yöntemler gibi doküman analizi de anlam çıkarmak, ilgili konu hakkında bir anlayış oluşturmak, ampirik bilgi geliştirmek için verilerin incelenmesini ve yorumlanmasını gerektirmektedir (Corbin \& Strauss, 2008).

\section{Çalışma grubu}

Çalışma grubu, Türkiye'deki üniversitelerin Türkçe Öğretimi Uygulama ve Araştırma Merkezlerinde Türkçe öğrenen A2 düzeyindeki 25 öğrenciden oluşmaktadır.

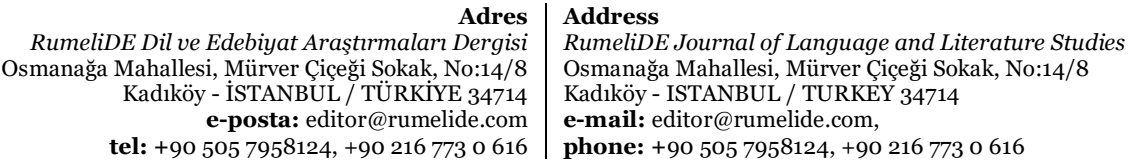


The habits of using language of structures of A2 level students learning Turkish as a foreign language / Ö. Çangal; A. Kıribiș (pp. 5664)

\section{Verilerin toplanması, analizi ve yorumlanması}

Araştırmada veri toplamak için öğrencilerin yazma kâğıtlarından yararlanılmıştır. Bu maksatla önce öğrencilere hem üretici dil becerilerinden olan yazma becerilerini hem de dil bilgisi yapılarını kullanabilmeleri için boş bir A4 kâğıdı verilmiş ve 45 dakikalık süre içerisinde kendilerine sunulan konulardan birisi ile ilgili bir kompozisyon yazmaları istenmiştir. Yazma etkinliği öncesinde çalışmanın güvenilirliğini etkilememek için öğrencilere, farklı bir konuda oluşturulan örnek üzerinden gerekli bilgilendirmeler yapılmıştır.

Öğrencilerin yazma kâğıtlarından elde edilen verilerin değerlendirilmesinde içerik analizinden yararlanılmıştır. "İçerik analizinde temelde yapılan işlem, birbirine benzeyen verileri belirli kavramlar ve temalar çerçevesinde bir araya getirmek ve bunları okuyucunun anlayabileceği bir biçimde düzenleyerek yorumlamaktır" (Yıldırım ve Şimşek, 2012). Bu aşamada öğrencilerin yazma etkinliklerinde kullanmış oldukları dil bilgisi yapıları konusu, kaynağı ve kavram alanı ilişkileri bakımından değerlendirilerek zamanlar, isimler, fiiller, ekler ve diğer şeklinde beş farklı kategoriye ayrılmıştır. Elde edilen bulgular yorumlanarak yabancı dil olarak Türkçe öğrenen A2 düzeyi öğrencilerinin kullanmayı tercih ettikleri dil bilgisi yapıları ile ilgili değerlendirmelerde bulunulmuştur.

\section{Bulgular}

Öğrencilerin kullanmayı tercih ettikleri dil bilgisi yapıları zamanlar, isimler, fiiller, ekler ve diğer şeklinde beş farklı kategoride incelenmiş, dil bilgisi içeriklerinin tasnifinde TMV Programı "düzeylere göre dil yapıları listesi" esas alınmıştır.

Öğrencilerin yazma kâğıtlarında en çok yararlandıkları zamanlar şu şekildedir:

Tablo 2. Zamanlar

\begin{tabular}{lc}
\hline Zamanlar & (f) \\
\hline Şimdiki Zaman & 127 \\
Görülen Geçmiş Zaman & 111 \\
Gelecek Zaman & 99 \\
Duyulan Geçmiş Zaman & 94 \\
Geniş Zaman & 41 \\
\hline
\end{tabular}

Tablo 2 incelediğinde öğrencilerin en çok "şimdiki zaman” ile (127 kez) cümleler kurdukları görülmüştür. Bunu 111 kullanımla "görülen geçmiş zaman”, 99 kullanımla "gelecek zaman”, 94 kullanımla "duyulan geçmiş zaman" izlemektedir. Öğrencilerin en az kullandıkları zaman ise 41 kullanımla "geniş zaman”dır.

Öğrencilerin yazma kâğıtlarında yararlandıkları dil bilgisi yapılarının gruplandırıldığı bir diğer tabloda ise isimler, yardımcı ve görevli sözcükler bulunmaktadır. İsimler, yardımcı ve görevli sözcükler kategorisinde yer alan dil bilgisi yapılarının kullanım sıklıklarına ilişkin veriler şu şekildedir:

Tablo 3. İsimler, Yardımcı ve Görevli Sözcükler

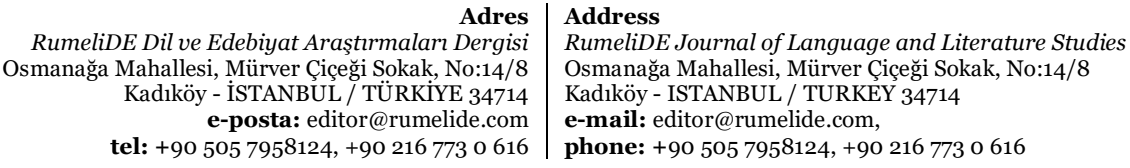

RumeliDE Dil ve Edebiyat Araştırmaları Dergisi el: +90 $5057958124,+902167730616$ 
Bağlaçlar: ile, ve, veya, ama, çünkü, hem ... hem, ne... ne, ya... ya... 366

$\begin{array}{lr}\text { Şahıs ve İşaret Zamirleri } & 216\end{array}$

$\begin{array}{lr}\text { Sifatlar } & 165\end{array}$

Zaman Zarfları (Dün, Bugün, Yarın; Önce, Şimdi, Sonra), Sıklık Zarfları 97

Gibi, Kadar (Benzetme/Karşılaştırma) 84

İkilemeler $\quad 21$

İlgi Zamiri (Benimki...)

$\begin{array}{ll}\text { Ünlemler } & 11\end{array}$

Tablo 3 incelediğinde öğrencilerin kompozisyonlarında en çok "bağlaçlar"dan (366 kez) yararlandığı görülmüştür. Bağlaçları 216 kullanımla "şahıs ve işaret zamirleri”, 165 kullanımla "sıfatlar", 97 kullanımla "zaman zarfları" ve 84 kullanımla "gibi, kadar (benzetme)” takip etmektedir. Öğrenciler tarafından “ikilemeler" 21, "ilgi zamiri” 12, "ünlemler” ise 11 kez kullanılmıştır.

Öğrencilerin ek kullanımlarına ilişkin veriler şu şekildedir:

Tablo 4. Ekler, İsim Çekim Ekleri ve Fiil Çekim Ekleri

\begin{tabular}{lc}
\hline Ekler, İsim Çekim Ekleri ve Fiil Çekim Ekleri & (f) \\
\hline İyelik Ekleri & 412 \\
Hâl Ekleri-Fiil İlişkisi & 252 \\
-mA Olumsuzluk Eki & 70 \\
Yapım Ekleri: -II/-SIz Ek Fiil & 69 \\
Yeterlilik Fiili & 25 \\
Slfat Fiil (-An) & 23 \\
Zarf Fiiller & 7 \\
Gereklilik Kipi & 6 \\
Dilek Şart Kipi & 5 \\
Ek Fiil Geniş Zaman & 3 \\
\hline
\end{tabular}

Tablo 4 incelediğinde 412 kullanım ile öğrenciler tarafından en fazla "iyelik ekleri”nin kullanıldığı görülmektedir. Bunu 252 kullanımla "hâl ekleri”, 70 kullanımla "olumsuzluk eki", 69 kullanımla "yapım ekleri (lı/sız)", 25 kullanımla "yeterlilik" ve 26 kullanımla "sıfat fiil” takip etmektedir. Öğrenciler "zarf fiilleri”, “gereklilik”, “dilek-şart” ve “ek fiil geniş zamanı” çok az kullanmaktadır.

Öğrencilerin sözcük ve cümle düzeyinde dil yapılarını kullanma alışkanlıklarına ilişkin veriler șu şekildedir:

Tablo 5. Sözcük ve Cümle Düzeyinde

\begin{tabular}{ll}
\hline Sözcük ve Cümle Düzeyinde & (f) \\
\hline Temel Soru Kelimeleri (5N1K) & 227 \\
Mesela, Örneğin & 147 \\
Sadece, Değil, Ayrıca/Aynı Zamanda & 95 \\
Bu Yüzden/Bu Sebeple & 88 \\
Kesinlikle/Mutlaka & 33 \\
Basit Emir Cümleleri & 11 \\
Doğrudan Anlatım (diye sor-/diye cevap ver-) & 3 \\
\hline
\end{tabular}

\footnotetext{
Adres | Address

Adres
RumeliDE Dil ve Edebiyat Arașttrmaları Dergisi Osmană̆a Mahallesi, Mürver Çiçeği Sokak, No:14/8 Kadıköy - ISTANBUL / TÜRKIYE 34714 e-posta: editor@rumelide.com

RumeliDE Journal of Language and Literature Studies Osmanağa Mahallesi, Mürver Çiçeği Sokak, No:14/8

Kadıköy - ISTANBUL / TURKEY 34714

e-mail: editor@rumelide.com, tel: +90 505 7958124, +90 2167730616 phone: +90 505 7958124, +90 2167730616
} 
The habits of using language of structures of A2 level students learning Turkish as a foreign language / Ö. Çangal; A. Kıribiș (pp. 5664)

Tablo 5 incelediğinde yazma kâğıtlarında 227 kullanım ile en fazla "temel soru kelimeleri”nin kullanıldı̆̆ görülmüştür. Bunu 147 kullanımla "örneğin, mesela”, 95 kullanımla "sadece, değil, ayrıca/aynı zamanda”, 88 kullanımla "bu yüzden/bu sebeple", 33 kullanımla "kesinlikle/mutlaka", 11 kullanımla "basit emir cümleleri” ve 3 kullanımla "doğrudan anlatım" izlemektedir.

İlk dört kategoride listelenemeyen dil bilgisi yapıları "diğer" başlığı altında listelenmiştir. Bu kategoriye ilişkin veriler şu şekildedir:

Tablo 6. Diğer

\begin{tabular}{ll}
\hline Diğer & (f) \\
\hline Basit Adlaştırmalar (-mAk iste-/-mAyI sev-) & 123 \\
-mAk için, -mAk üzere, -mAsI için & 85 \\
Üstünlük Derecesi: en & 71 \\
-I beğen-, -I beğenme-, -I tercih et-, -I seç- & 70 \\
Karşlaştırma Yapıları: -DAn, -DAn daha ... & 69 \\
-DAn beri, -DIr & 52 \\
-DAn önce/-DAn Sonra & 41 \\
-mAdAn önce, -DIktAn sonra & 41 \\
-cA, -A göre & 35 \\
-DAki & 19 \\
-DAn -A kadar & 17 \\
\hline
\end{tabular}

"Basit adlaştırmalar (-mayı sev-/-mak iste-)" öğrenciler tarafından 123 kez kullanılmıştır. "-mAk için, -mAk üzere, mAsI için” 85, üstünlük bildiren "en” 71, “-I beğen-, -I beğenme-, -I tercih et-, -I seç-” 70, karşılaştırma yapıları olan “-DAn, -DAn daha ...” 69 ve "-DAn beri, -DIr" 52 kez öğrenciler tarafından tercih edilirken “DAn önce/-DAn sonra”, “-mAdAn önce, -DIktAn sonra”, “-cA, -A göre”, “-DAki” ve “-DAn -A kadar” yapıları da öğrencilerin kompozisyonlarında yer almıştır.

\section{Sonuç}

Yabancı dil olarak Türkçe öğretimi faaliyetleri kurumlara ve kurumların belirlediği dil politikalarına göre farklılıklar göstermekte, her kurum kendi seçtiği dil öğretim seti üzerinden yabancılara Türkçe öğretmektedir. Belirli bir plan dâhilinde Türkçe öğrenen yabancıların öğrendikleri dil bilgisi yapılarından hangilerini ne sıklıkla kullandıklarının tespit edilmesi ders süreçlerinin planlanması, öğretim programlarının ve ders kitaplarının yeniden düzenlenmesi aşamalarında uzmanlara önemli bir veri kaynağı sunacaktır.

Bu nedenle araştırma kapsamında Türkiye'deki üniversitelerin Türkçe Öğretimi Uygulama ve Araştırma Merkezlerinde Türkçe öğrenen A2 düzeyindeki 25 öğrenciye ait yazma kâğıtları incelenmiş ve TMV Programındaki dil bilgisi yapıları listesinden hareketle öğrencilerin dil bilgisi yapılarını kullanma alışkanlıklarına yönelik tespitlerde bulunulmuştur.

Çalışmanın veri kaynağı olan yazma etkinliklerinde öğrenciler kendi istedikleri konularda kompozisyon yazmıştır. Bu tür çalışmalarda öğrencilere belirli bir konu diretilmediğinde öğrencilerin daha başarılı olacaklarını düşündükleri ve kendilerini daha rahat hissettikleri konularda yazdıkları görülmüştür. Çalışma grubunu oluşturan öğrencilerin tamamı Türkiye'de yaşamaktadır. Dolayısıyla bu öğrencilerin yazma etkinliklerinde günlük hayatta en çok ihtiyaç duydukları ve en fazla kullanmak zorunda oldukları dil bilgisi

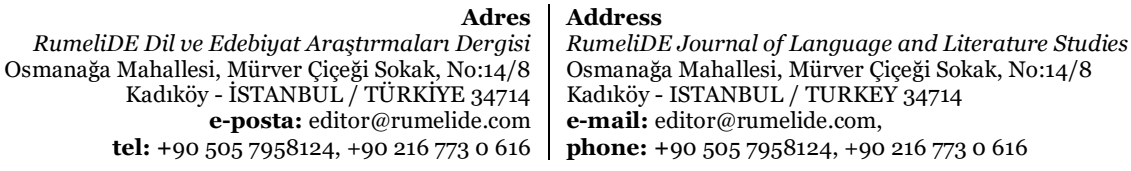


yapılarına yer verecekleri düşünülmüştür. Nitekim öğrencilerin yazma kâğıtları incelendiğinde sırası ile en çok şimdiki, görülen geçmiş, gelecek ve duyulan geçmiş zamanın kullanıldığı; onları geniş zamanın izlediği tespit edilmiştir.

Yabancılara Türkçe öğretimi amacıyla Ankara Üniversitesi (2012), Gazi Üniversitesi (2014), İstanbul Üniversitesi (2016) ve Yunus Emre Enstitüsü (2016) tarafından hazırlanan ders kitapları ve TMV programı "düzeylere göre dil yapıları listesi” incelendiğinde zamanların öğrencilere aynı sıra ile verildiği görülmektedir. Buna göre hazırlanan ders içerikleri ile öğrencilerin kullanım alışkanlıklarının örtüştüğü ortaya çıkmaktadır. Şimdiki zamanın en çok kullanılan zaman olmasında, bu zamanın "Yarın okula gidiyorum." ve "Her hafta sonu piknik yapıyoruz." örneklerinde olduğu gibi gelecek zaman ve geniş zamanın yerine kullanılabilme özelliğinin de etkisi bulunmaktadır.

Türkçede geçmiş zaman "görülen" ve "duyulan" şeklinde ikiye ayrılırken pek çok dilde böyle bir kullanımın olmadığı bilinmektedir. Her iki geçmiş zamanın kullanım sıklıkları toplandığında aslında öğrencilerin 205 kullanımla en fazla geçmiş zaman ile cümle kurdukları ortaya çıkmaktadır. Yazma çalışmalarında gelecek zaman ve şimdiki zaman ile kurulacak örneklerde öğrencilerin hayal güçlerinden daha fazla yararlanması gerekirken geçmiş zaman ile kurulacak cümlelerde yalnızca başına gelen olayları ifade etmeleri gerekmektedir. Bu da öğrencilerin hedef dilde yazmalarını kolaylaştırmakta, öğrenci tecrübe ettiği bir konuda yazmakta zorlanmamaktadır.

Bağlaçlar gerek konuşma gerekse yazı dilinde sıklıkla kullanılmaktadır. Katılımcıların kâğıtları incelendiğinde de öğrencilerin yazılarında sıklıkla "ile, ve, veya, ama, çünkü, hem ... hem, ne ... ne, ya ... ya" bağlaçlarından yararlandıkları görülmüștür. Zamirler, sıfatlar, zaman zarfları ve gibi/kadar edatları da yazı dilinde sıklıkla kullanılmaktadır. İkilemeler, ilgi zamiri ve ünlemler ise öğrenciler tarafından daha az kullanılmaktadır.

İyelik ekleri ve hâl ekleri öğrenciler tarafından çok fazla kullanılmaktadır. Öğrenciler iyelik eklerinin yazımında çok fazla sorun yaşamazken hâl eklerinin kullanımında bazı sorunlarla karşılaşmakta, hangi düzeyde olursa olsun hâl eklerinin fiillerle birlikte kullanımında hata yapmaktadır. Yapılan çalışmalar da yabancı dil olarak Türkçe öğrenenlerin hâl eklerinin kullanımında sorun yaşadığını ortaya koymaktadır (bk. Çangal ve Başar, 2018; Barcın, 2019; Altuntaş, 2020; Korkmaz, 2021). Hâl eklerinin kullanımına çok fazla ihtiyaç duyulması, fakat buna rağmen öğrencilerin hâl eklerini kullanırken çok fazla hata yapmaları önemli bir sorundur.

"Ne, ne zaman, nerede, nasıl, neden ve kim" gibi temel soru ifadeleri ile "mesela, örneğin" gibi örneklendirme ifadeleri yazı dilinde sıklıkla kullanılmaktadır. Yine öğrenciler "sadece, değil, ayrıca, aynı zamanda, bu yüzden ve bu sebeple" yapılarını yazılarında genellikle kullanmayı tercih etmektedir.

Öğrencilerin yazma kâğıtları incelendiğinde TMV programı "düzeylere göre dil yapıları listesi” içerisinde A1 ve A2 düzeyi bölümünde yer alan "istek/dilek I. çekim, isim tamlamaları, ek fiil belirli geçmiş zaman, sıralama sayıları, -DAn hoşlan-, ek fiil görülen ve duyulan geçmiş zaman ve zarflar"ın öğrenciler tarafından yazma çalışmalarında kullanılmadığı tespit edilmiştir.

Araştırmaya katılan öğrenciler Türkiye'deki farklı TÖMER'lerde farklı dil öğretim setlerini kullanarak Türkçe öğrenmiştir. A2 düzeyini tamamlayan öğrencilerin yazma etkinliklerinde hangi dil bilgisi yapılarını daha çok kullandıklarını ve hangi yapılara ihtiyaç duymadıklarını tespit edebilmek amacıyla hazırlanan bu çalışmanın program geliştirme ve ders materyali tasarlamada uzmanlara yardımcı olacağı

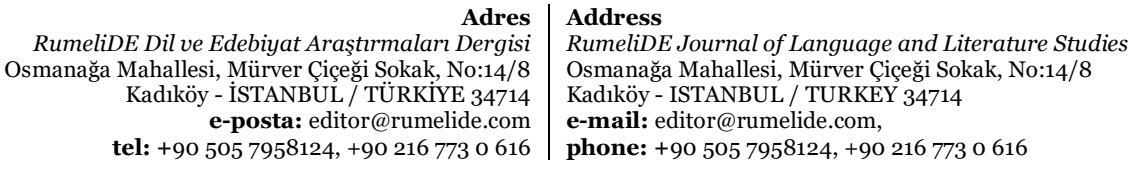


düşünülmektedir. Gerçekleștirilecek benzer çalışmalarla hem genel hem de özel amaçlı Türkçe öğretimine yönelik öncelikli dil bilgisi yapılarının tespit edilmesi yabancılara Türkçe öğretimi alanının gelişmesine katkı sağlayacaktır.

\section{Kaynakça}

Altuntaş, İ. G. (2020). An examination on mistakes of case suffixes' usage in written expression of foreigners learning Turkish. Cypriot Journal of Educational Science. 15(6), 1659-1671.

Ankara Üniversitesi TÖMER (2012). Yeni Hitit Yabancılar İçin Türkçe Ders Kitabı. Nadir Engin Uzun (Ed.). Ankara: Ankara Üniversitesi Basımevi. ISBN: 978-975-482-802-3

Barcın, S. (2019). Kırgızlara Türkçe Öğretiminde Ad Durum Eklerinin Yeri. Aydın TÖMER Dil Dergisi, 4(1), 115. ISSN 2458-7818

Corbin, J. \& Strauss, A. (2008). Basics of qualitative research: Techniques and procedures for developing grounded theory. Thousand Oaks: Sage.

Çangal, Ö. ve Başar, U. (2018). Yabancllara Türkçe Öğretiminde Ad Durum Eklerinin Yan İşlevlerinin Öğretilmesi, 21. Yüzyılda Eğitim ve Toplum-Eğitim Bilimleri ve Sosyal Araştırmalar Dergisi, 7(19), 155189, ISSN: 2147-0928.

Gazi Üniversitesi TÖMER (2014). Yabancılar için Türkçe B2 orta düzey. Mustafa Kurt ve Nezir Temür (Ed.). Ankara: Kalkan Matbaası.

İstanbul Üniversitesi Dil Merkezi (2016). İstanbul yabancılar için Türkçe ders kitabı B2. Fatma Bölükbaş ve Mehmet Yalçın Yılmaz (Ed.). İstanbul: Kültür Sanat Basımevi.

Korkmaz, C. B. (2021). Yabancı dil olarak Türkçenin öğretiminde kullanılan temel seviye fiillerin istem (valenz) görünümleri. Bayburt Eğitim Fakültesi Dergisi, 16(Özel Sayı), 91-107.

TELC (2013). Diller İçin Avrupa Ortak Öneriler Çerçevesi-Öğrenim, Öğretim ve Değerlendirme. Germany: TELC GmbH.

Türkiye Büyük Millet Meclisi. (2021, Temmuz). Avrupa Konseyi (AK). https://www.tbmm.gov.tr/ul_kom/akpm/genel_bilgi.htm

Türkiye Maarif Vakfı (2020). Türkçenin yabancı dil olarak öğretimi programı. İstanbul. Web: https://www.turkiyemaarif.org/uploads/Turkcenin_Yabanci_Dil_Olarak_Ogretimi_Programi_2_Bas ki.pdf adresinden 23 Mayıs 2021 tarihinde alınmıştır.

Wach, E. (2013). Learning about qualitative document analysis. Web: https://www.ids.ac.uk/publications/learning-about-qualitative-document-analysis/ adresinden 25 Mayıs 2021 tarihinde alınmıştır.

Yunus Emre Enstitüsü (2016). Yedi iklim Türkçe öğretim seti ders kitabı. Erol Barın ve Cihan Özdemir (Ed.). Ankara: Yunus Emre Enstitüsü Yayınları. ISBN: 978-605-87010-2-1

Adres
RumeliDE Dil ve Edebiyat Araşttrmaları Dergisi Osmanağa Mahallesi, Mürver Çiçeği Sokak, No:14/8 Kadıköy - İSTANBUL / TÜRKIYE 34714 e-posta: editor@rumelide.com tel: +90 $5057958124,+902167730616$
Address

RumeliDE Journal of Language and Literature Studies

Osmanağa Mahallesi, Mürver Çiçeği Sokak, No:14/8

Kadıköy - ISTANBUL / TURKEY 34714

e-mail: editor@rumelide.com,

phone: +90 5057958124, +90 2167730616 